\title{
Modifikasi Metode Isolasi Sel Endotel Pembuluh Darah Otak (EPDO) Tikus: Teknik Dasar Kultur Sel Primer di Bidang Neurosains
}

\author{
Ahmad Faried, ${ }^{1,2}$ Muhammad Zafrullah Arifin, ${ }^{1}$ Agung Budi Sutiono, ${ }^{1}$ \\ Danny Halim, ${ }^{2}$ Tono Djuwantono, ${ }^{2}$ Tri Hanggono Achmad ${ }^{2}$ \\ ${ }^{1}$ Departemen Bedah Saraf; ${ }^{2}$ Grup Peneliti Sel Punca, Unit Penelitian Kesehatan, \\ Fakultas Kedokteran Universitas Padjadjaran, Rumah Sakit Hasan Sadikin
}

\begin{abstract}
Abstrak
Metode konvensional isolasi sel endotel pembuluh darah otak (EPDO) masih tergolong sulit, sehingga upaya mendapatkan populasi murni sel ini adalah tantangan. Pada penelitian ini dilakukan isolasi endotel dari tikus Wistar dan mencit C57/Bl6, berdasarkan protokol the care and use of laboratory animals, Universitas Gunma, Jepang. Modifikasi metode isolasi adalah menggunakan gradasi bovine serum albumin (BSA), bukan Dextran-70 yang umumnya dipakai, untuk memisahkan sel EPDO yang bersatu menjadi sel EPDO tunggal. Penelitian ini dilakukan di laboratorium sel kultur, Universitas Padjadjaran bekerjasama dengan Universitas Gunma, Jepang, Januari 2008-Juni 2009. Uji hasil isolasi dan karakteristik sel EPDO dilakukan dengan teknik imunofloresen. Ekspresi tight junction ZO-1, menunjukkan sel EPDO membentuk selapis sel utuh, rapat, tidak bertumpuk dan kompak, sesuai dengan karakteristik dinding EPDO. Fenotip sel EPDO dikonfirmasi dengan acethylated LDL, faktor von Willebrand dan CD31. Penghancuran kapiler dengan collagenase/dispase masih menghasilkan populasi sel yang terkontaminasi perisit. Kontaminasi dimurnikan dengan menggunakan puromycin, tingkat pemurnian sel EPDO mencapai 98,3\%. Simpulan, teknik modifikasi berhasil mengisolasi sel EPDO tikus dan mencit, tanpa melakukan intervensi genetik. Puromycin dapat digunakan untuk memurnikan sel EPDO. [MKB. 2010;42(4):161-8].
\end{abstract}

Kata kunci: Metode modifikasi isolasi sel EPDO, pembuluh sawar otak, teknik pemurnian

\section{Isolation Modified-Method of Mouse-Brain Microvessel Endothelial Cells: Primary Cell Culture Technique in Neuroscience}

\begin{abstract}
Isolation method to obtain pure BMVECs is hard to be done consistently and remains a challenge. In this study, we isolated BMVECs from Wistar rat and C57/B16 mouse from Japan SLC. All procedures performed according to guidelines for the care and use of laboratory animals of Gunma University, Japan. The modification of isolation method was using bovine serum albumin (BSA) gradation, not Dextran-70 in which generally used, to separate clusters of BMVECs into single cell. This study was done at Universitas Padjadjaran, in colaboration with Gunma University, Japan, January 2008-June 2009. Further, characteristic and purification results were proven by imunofluorescene staining. The results showed that staining of tight junction, ZO-1, formed a monolayer, tightly packed, non-overlapping and contact-inhibited BMVECs, as expected for a vessel wall endothelial. ECs phenotype confirmed by acethylated LDL, von Willebrand and CD31. The digestion of capillaries generated contaminating pericytes. Contamination was purified using puromycin and the results considered satisfactory (98.3\%). In conclusion, our modification procedure allows the isolation of primary rat and mouse BMVECs, which form an endothelial-like monolayer in few days. Puromycin can be used for purification of primary rat and mouse BMVECs. [MKB. 2010;42(4):161-8].
\end{abstract}

Key words: Blood brain barrier, isolation modified-method of mouse-BMVECs, purification methods 


\section{Pendahuluan}

Sel endotel adalah sel poligonal yang tersusun sebagai sel selapis pada dinding pembuluh darah. Lapisan sel endotel tersusun rapat, berjajar dan memiliki dua sisi, yaitu satu sisi menghadap ke dalam lumen pembuluh darah, sedangkan sisi lainnya menghadap membran basalis. Sel endotel pembuluh darah merupakan regulator berbagai reaksi biologis dan berperan dalam banyak fungsi fisiologis tubuh. Sel endotel pembuluh darah merupakan sel yang sangat aktif berinteraksi dan menghubungkan sel darah dengan jaringan di sekitarnya. Selain itu, sel endotel pembuluh darah merupakan barier semipermiabel yang dinamis dalam organ-organ tubuh yang menjadi tempat keberadaannya. Sel endotel pembuluh darah juga berperan dalam regulasi endokrin dan parakrin di dalam tubuh, sehingga sering dianggap sebagai jaringan metabolisme multifungsi. ${ }^{1,2}$

Seluruh organ dalam tubuh mendapat darah dari pembuluh darah, maka sel endotel pembuluh darah tersebar di seluruh tubuh manusia. Salah satu jenis sel endotel yang berperan penting dalam kelangsungan hidup manusia, adalah sel endotel pembuluh darah otak (EPDO). Sel-sel tersebut merupakan stuktur utama yang menyusun pembuluh sawar otak (blood brain barier; BBB). BBB terlibat dalam mekanisme fisiologis dan patofisiologis jaringan otak, contohnya dalam hal distribusi nutrisi dari sel darah ke jaringan otak, transmigrasi leukosit dari sirkulasi darah, pembentukan pembuluh darah otak yang baru dan memompa senyawa yang bersifat toksik dari otak ke sistem pembuangan. Metode isolasi dan kulturisasi sel EPDO, terutama dari manusia dan mamalia, ${ }^{3,4}$ telah menjadi prosedur rutin yang memberi kontribusi dalam pengembangan pengetahuan mengenai fungsi biologis peredaran darah otak, terutama karakteristik biologis sel penyusun BBB. Keberhasilan dalam mengisolasi sel EPDO akan memberikan gambaran ilmiah BBB yang sebenarnya.

Hasil penelitian in vitro (di dalam cawan petri) tentang patofisiologi suatu penyakit, akan menjadi lebih akurat dan semakin dipercaya bila model penelitian yang digunakan menyerupai situasi sebenarnya pada penelitian in vivo (percobaan binatang). Metode isolasi dan kulturisasi sel EPDO konvensional yang ada jarang mendapatkan populasi murni sel endotel pembuluh darah otak. Seringkali, populasi sel
EPDO yang hendak diisolasi terkontaminasi oleh sel-sel otak lain yang melekat erat dengannya, seperti membran basalis, otot polos aktin, perisit, dan astrosit. ${ }^{5}$ Selain proses isolasi yang kompleks dan sulit dilakukan, hambatan yang seringkali dihadapi pascaupaya isolasi sel EPDO adalah sulitnya melakukan perbanyakan sel hasil isolasi dan pendeknya waktu hidup sel dalam cawan petri. Untuk mendapatkan sampel yang cukup, peneliti juga membutuhkan jumlah hewan percobaan yang banyak.

Pada penelitian ini, dilakukan isolasi dan kultur primer sel EPDO tikus memakai metode dari Deli dkk. ${ }^{6}$ dengan modifikasi. Modifikasi yang dilakukan adalah dengan menggunakan gradasi bovine serum albumin (BSA). Metode isolasi konvensional pada umumnya tidak menggunakan BSA, melainkan Dextran-70, untuk memisahkan kumpulan sel EPDO menjadi sel-sel tunggal pada saat konfluensi tercapai. Kami memakai puromycin untuk memurnikan populasi sel EPDO. ${ }^{9}$

\section{Metode}

\section{Isolasi EPDO-primer, pemurnian, dan kondisi kultur}

Tikus jantan dewasa, jenis tikus Wistar dan mencit C57/B16, umur 6-8 minggu, (SLC, Hamamatsu, Japan) dibius dengan diethyl ether (Wako, Japan). Selanjutnya dilakukan dislokasi tulang leher dan reseksi korteks serebri, lapisan meningen, dan pembuluh darah besar di permukaan. Sesudah itu korteks serebri dicacah dan dihancurkan secara enzimatik dengan memakai $1,5 \mathrm{mg} / \mathrm{mL}$ enzim dispase (Gibco) dalam Dulbecco's modified eagle medium (DMEM; Sigma) selama satu jam pada suhu $37^{\circ} \mathrm{C}$. Untuk membersihkan lapisan mielin, pelet yang terkumpul diresuspensi dalam BSADMEM $(20 \% \mathrm{w} / \mathrm{v})$, lalu disentrifugasi dengan kecepatan $2.400 \mathrm{rpm}$ selama 20 menit pada suhu ruangan. Pelet, lalu diresuspensi dan dihancurkan kembali dengan memakai $1 \mathrm{mg} / \mathrm{mL}$ collagenasedispase (Roche) dalam DMEM-Hepes (Gibco) selama satu jam pada suhu $37^{\circ} \mathrm{C}$. Populasi sel yang terdiri dari sel EPDO dipisahkan dari sel lainnya dengan menggunakan 30\% continuous Percoll-gradient (Amersham Biosciences). Sel EPDO selanjutnya dikultur dalam cawan petri yang telah dilapisi collagen type I (Iwate, Japan). Sel EPDO dikultur dalam medium DMEM 
dengan pemberian suplemen $10 \%$ fetal bovine serum (Gibco), serta ditambahkan sebanyak 20 $\mathrm{U} / \mathrm{mL}$ heparin-sodium (Fusouyakuhin, Japan), penicillin streptomycin (Gibco), $10 \mathrm{ng} / \mathrm{mL}$ EGF (Peprotech, London), dan $10 \mathrm{ng} / \mathrm{mL}$ bFGF (Peprotech), 20 ng/mL VEGF (Peprotech). Untuk mendapatkan populasi sel EPDO yang murni, maka dilakukan penambahan $4 \mu \mathrm{g} / \mathrm{mL}$ puromycin (Sigma) pada media kultur. Kulturisasi dilakukan selama dua hari seperti yang dijelaskan oleh Perriére dkk. ${ }^{9}$

\section{Metabolisme Ac-LDL (acetylated-low density lipoprotein) sebagai molekul penanda sel EPDO}

Kulturisasi sel EPDO dilakukan pada 8 well-micro glass steril (Matsunami, Japan) yang telah dilapisi kolagen tipe I (Sigma). Setelah mencapai konfluensi, medium diganti dengan medium baru yang telah ditambahkan Ac-LDL dan dilabel dengan fluorescent dye Alexa fluor 488 (green fluorescence, Invitrogen). Tindakan selanjutnya, melakukan inkubasi selama 4 jam pada $37^{\circ} \mathrm{C}$. Visualisasi sel yang telah memetabolisme AcLDL diamati dengan menggunakan confocal laser scanning microscopy (LSM 510 Meta, Zeiss).

\section{Teknik imunofloresen untuk melihat marker EPDO}

Sel EPDO dikultur dalam cawan kultur steril yang terdiri dari 8 well (Matsunami), kemudian dicuci $2 \mathrm{x}$ dengan PBS. Fiksasi dilakukan dengan 4\% $(\mathrm{w} / \mathrm{v})$ paraformaldehyde (PFA) dingin selama 10 menit. Sel EPDO kemudian dicuci kembali dengan PBS, lalu ditambahkan cairan blocking yang terdiri dari $10 \%(\mathrm{v} / \mathrm{v})$ normal gout serum (NGS) dan 0,4\% (v/v) Triton X-100. Selanjutnya sampel diinkubasi selama 30 menit pada suhu ruangan, kemudian dilakukan pemberian antibodi primer selama 1 jam pada suhu ruangan. Antibodi yang dipakai sebagai molekul penanda dalam studi ini adalah: rabbit anti-von Willebrand factor VIII(vWF, Santa Cruz); rat anti-CD-31 (PECAM1, BD Pharmingen); rabbit anti-ZO-1 (Zymed); mouse anti- $\alpha$-smooth muscle actin ( $\alpha$-SMA, Sigma); TO-PRO-3 (Molecular Probes). Setelah pemberian antibodi pertama, sel EPDO dicuci kembali dengan PBS, antibodi kedua dapat diberikan dalam PBS (pengenceran 1:1.000) yang mengandung $3 \%(\mathrm{v} / \mathrm{v})$ NGS dan $0,1 \%(\mathrm{v} / \mathrm{v})$ triton $\mathrm{X}-100$. Inkubasi dilakukan selama 30 menit pada suhu ruangan. Antibodi kedua yang dipakai adalah: anti-rabbit Alexa Flour 488 (green fluorescence, Invitrogen); anti-rat FITC (green fluorescence), anti-mouse, dan anti-rabbit Rodhamine (red fluorescence, Jackson Immuno Research). Setelah sel EPDO dicuci, dilakukan fiksasi dengan 4\% (v/v) PFA selama 10 menit pada suhu ruangan. Hasil fiksasi dicuci kembali, lalu diberi cover slips. Spesimen yang telah dibuat dilindungi menggunakan vectashield mounting medium (Vector Laboratories), sebelum diamati menggunakan confocal laser scanning microscopy(LSM 510 Meta, Zeiss).

\section{Proliferasi sel EPDO}

EPDO dibiakkan dalam microglass steril yang terdiri dari 8 well (Matsunami). Untuk mendeteksi 5-bromodeoxyuridine (BrdU) sebagai penanda proliferasi, sel EPDO dipaparkan dengan $10 \mu \mathrm{M}$ BrdU (Roche Diagnostics) dan dikultur selama 16 jam pada suhu $4^{\circ} \mathrm{C}$. Setelah inkubasi, sel EPDO difiksasi dengan $4 \%$ paraformaldehyde selama 10 menit. Selanjutnya diinkubasi kembali dengan antibodi pertama dan kedua. Sel EPDO difiksasi ulang dengan $4 \%$ paraformaldehyde selama 5 menit, lalu diinkubasi dengan $2 \mathrm{M}$ hydrochloric acid selama 20 menit untuk mendenaturasi DNA. Spesimen lalu dinetralkan dengan $0,1 \mathrm{M}$ sodium tetraborate $(\mathrm{pH}$ 8,5). Sel EPDO diinkubasi dengan rat monoclonal anti-BrdU antibody (Oxford) dan fluorescence rhodamine-conjugated donkey anti-rat antibodies (Jackson). BrdU yang merupakan analog thymidine, akan masuk ke rantai DNA pada fase $\mathrm{S}$ dalam siklus sel, sehingga ekspresi BrdU pada EPDO melambangkan kemampuan sel EPDO untuk berproliferasi.

\section{Analisis statistik}

Analisis statistik dilakukan dengan menggunakan Stat view software (ver. 5.0, SAS Institute Inc., $\mathrm{NC}$ ). Perbedaan dianggap bermakna bila $\mathrm{p}<0,05$.

\section{Hasil}

\section{Hasil isolasi primer sel EPDO, pemurnian, kondisi kultur, fenotip, dan molekul penandanya}

Isolasi primer sel EPDO dilakukan melalui dua tahap degradasi enzimatik untuk memisahkan sel EPDO dari parenkim dan membran basal. Sehari setelah sel EPDO disemaikan dalam cawan kultur, dengan mikroskop fase kontras terlihat populasi 


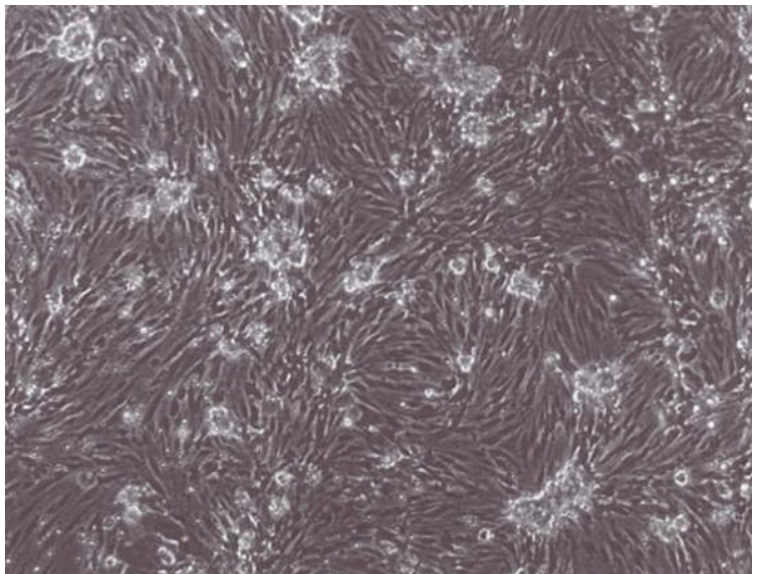

Gambar 1 Hasil Isolasi Primer Sel EPDO

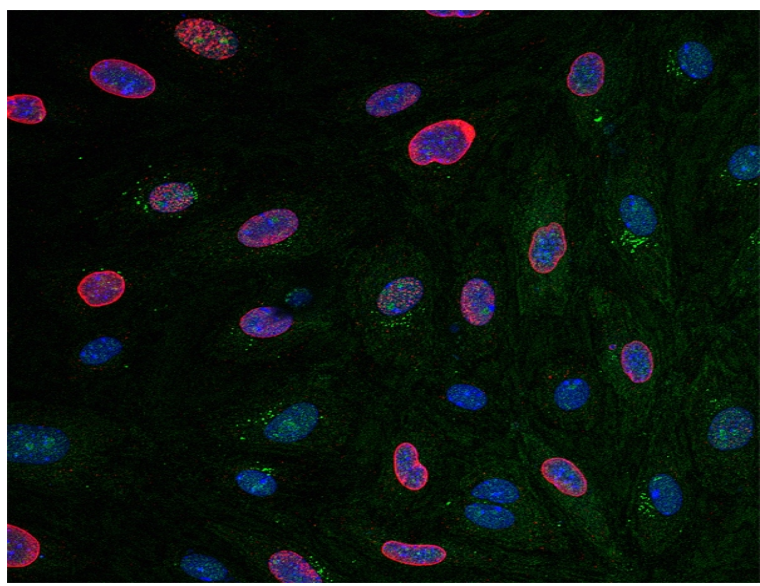

Gambar 3 Hasil Isolasi Primer Sel EPDO yang Dilabel dengan vWF (Hijau) dan BrdU (Merah)

sel berbentuk spindle yang berhubungan erat satu sama lain yang merupakan ciri khas sel EPDO (Gambar 1).

Molekul penanda Ac-LDL dapat digunakan untuk membuktikan keberadaan sel EPDO. ${ }^{10}$ Hasil penelitian ditampilkan pada Gambar 2, sel EPDO yang berhasil kami isolasi menunjukkan gambaran imunofloresen Ac-LDL yang tampak seperti titik-titik hijau merata di dalam sitoplasma sel.

Pewarnaan imunofloresen faktor pembekuan VIII (vWF) adalah marker spesifik sel endotel, sehingga dijadikan molekul penanda standar untuk sel endotel pada sistem kultur. ${ }^{11}$ BrdU digunakan sebagai molekul penanda proliferasi (Gambar 3).

Protein zonula occludens-1 (ZO-1) berfungsi sebagai tight junction $\mathrm{BBB}$, juga merupakan

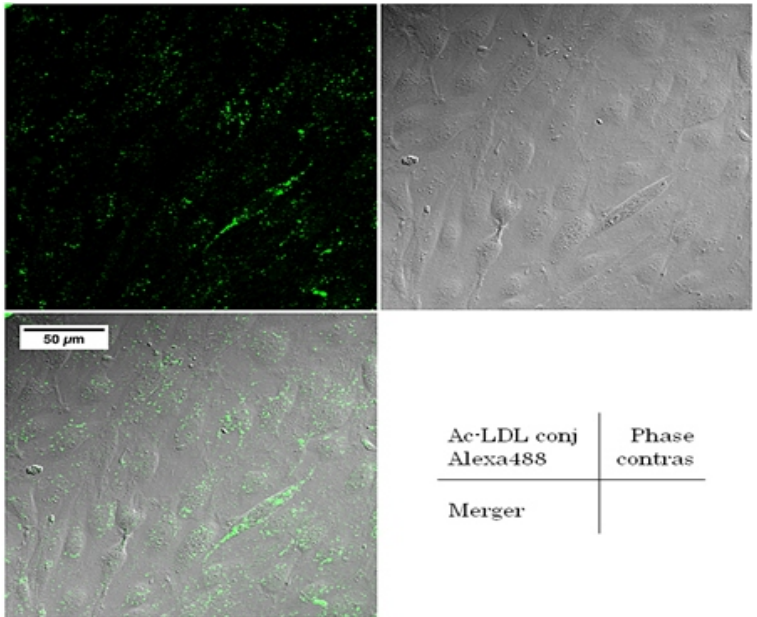

Gambar 2 Hasil Isolasi Primer Sel EPDO yang Dilabel dengan Molekul Penanda Ac-LDL (Hijau)

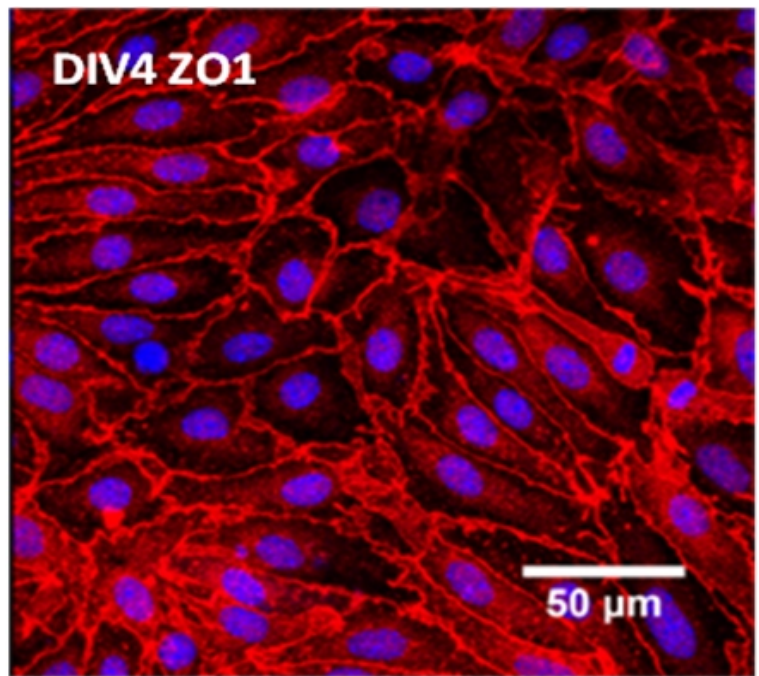

Gambar 4 Hasil Isolasi Primer Sel EPDO yang Dilabel dengan ZO-1 (Garis Merah) dan TO-PRO-3 (Biru)

molekul penanda penting untuk EPDO. Ekspresi serta lokalisasi ZO-1 pada isolasi sel EPDO dibuktikan dengan menggunakan pewarnaan imunofloresen untuk ZO-1 (Gambar 4).

\section{Hasil pemurnian sel EPDO secara primer}

Sel EPDO hasil isolasi, diterapi menggunakan puromycin $4 \mu \mathrm{g} / \mathrm{mL}$ selama dua hari.

Sel EPDO terbukti tumbuh sempurna pada hari ke-3. Untuk menghitung keberhasilan teknik pemurnian ini, sel EPDO yang telah diterapi, dengan dan tanpa puromycin kemudian diwarnai dengan dua molekul penanda imunofloresen anti- 


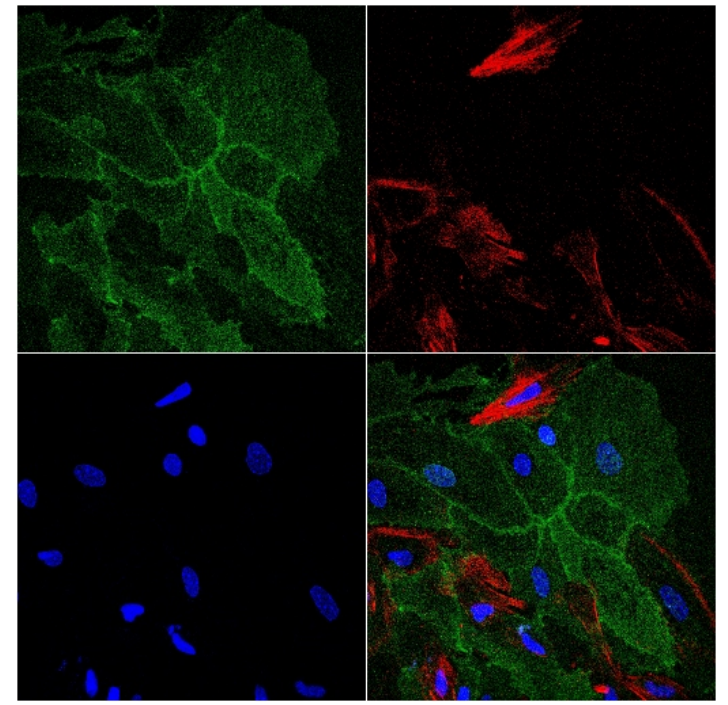

A

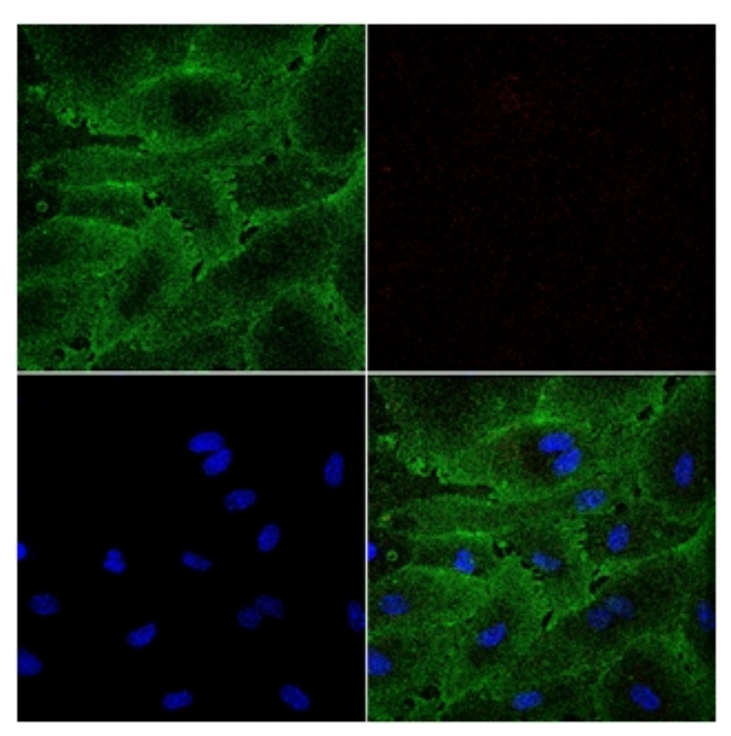

B

Gambar 5A Hasil Isolasi Primer Sel EPDO Tanpa Puromycin; 5B Hasil Isolasi Primer Sel EPDO dengan Pemurnian Puromycin. Ekspresi CD-31 (PECAM-1, Hijau), AlphaSmooth Muscle Actin (a-SMA, Merah) dan Inti Sel (To-Pro-3, Biru)

CD-31 dan $\alpha$-SMA. Ternyata hasil penelitian menunjukkan banyaknya kontaminasi sel-sel otak lain di samping sel EPDO pada sampel yang tidak diterapi dengan puromycin (Gambar 5A), dibandingkan dengan sampel yang diterapi
Purity mvec isolated using puromycin at DIV6

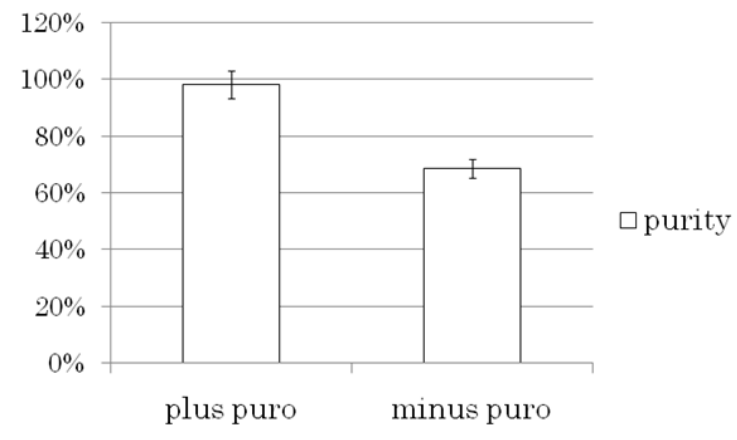

Gambar 6 Sampel yang Tidak Diterapi Puromycin, Nilai Kemurniannya $68,6 \%$ (minus puro), sedangkan Sampel yang Diterapi Puromycin, Nilai Kemurniannya Mencapai $\mathbf{9 8 , 3 \%}$ (plus puro)

dengan puromycin (Gambar 5B). Sel EPDO yang mengekspresikan CD-31 (PECAM-1), $\alpha$-SMA dan To-Pro-3 dihitung pada empat daerah yang dianggap mewakili. Sampel yang tidak diterapi dengan puromycin, nilai kemurniannya $68,6 \%$, sedangkan yang diterapi dengan puromycin, nilai kemurniannya meningkat hingga 98,3\% (Gambar 6) dengan nilai $p<0,05$.

\section{Pembahasan}

Model penelitian in vitro akan sangat bermanfaat apabila hasil dan informasi yang didapatkan menggambarkan situasi sama dengan in vivo. Berdasarkan pada literatur, cara isolasi dan kulturisasi sel EPDO lebih sulit dilakukan pada spesies tikus dibandingkan dengan spesies lainnya (bovine dan babi). Hal ini terbukti dengan banyaknya sel EPDO yang dijual komersial, merupakan hasil transfeksi yang membuat usia hidup sel tersebut menjadi kekal. Pada penelitian ini dilakukan uji metode isolasi konvensional ${ }^{12}$ menggunakan teknik modifikasi yang kami kembangkan.

Berdasarkan pada jumlah sel EPDO hari ke-3, gradasi BSA terbukti lebih efektif (1.500 sel) dibandingkan dengan penggunaan Dextran-70 yang umumnya dipakai (297 sel; Faried dkk. unpublished observation). Modifikasi juga dilakukan dengan menambahkan beberapa faktor pertumbuhan utama, seperti epidermal growth factor (EGF) $10 \mathrm{ng} / \mathrm{mL}$, basic fibroblast growth factor (bFGF) $10 \mathrm{ng} / \mathrm{mL}$, vascular endothelial 
growth factor (VEGF) $20 \mathrm{ng} / \mathrm{mL}$, dan puromycin. Bovine serum albumin merupakan alat bantu mekanik yang bersifat menimbulkan banyak buih sehingga didapatkan sel EPDO dalam jumlah besar dan terlepas dari kelompokan selnya. Sel yang didapat, selanjutnya dikultur dalam cawan kultur yang dasarnya telah dilapisi kolagen. Populasi sel hasil kulturisasi, memberikan gambaran khas sel endotel, seperti bentuk spindle selapis dalam susunan yang rapat dan padat, tidak bertumpuk dan saling berdekatan. Gambaran ini sesuai dengan yang diharapkan, yaitu ciri sel endotel yang membentuk dinding pembuluh darah. Ciri khas lain sel endotel juga diuji dengan molekul penanda, yaitu faktor von Willebrand dan CD-31 (PECAM-1). Meskipun telah berhasil dilakukan, populasi sel yang didapat dari isolasi sel EPDO masih terkontaminasi sel-sel perisit. Teknik pemurnian yang dijelaskan oleh Perriére dkk. ${ }^{9}$ merupakan terapi yang sistematis dengan menambahkan $4 \mu \mathrm{g} / \mathrm{mL}$ puromycin ke dalam medium kultur selama 2 hari, segera setelah isolasi sel EPDO berhasil dilakukan. Langkah ini dilakukan untuk menghilangkan sel-sel yang menjadi kontaminan dan mencapai nilai kemurnian hingga 98,3\%. Teknik pemurnian ini tidak mengubah sifat, morfologi dan kecepatan tumbuh sel EPDO yang diterapi. ${ }^{13}$

Masalah terbesar dalam hal isolasi dan kulturisasi sel secara primer, termasuk sel EPDO, adalah inkonsistensi hasil yang didapatkan dari metode isolasi, terutama saat dilakukan upaya repetisi metode isolasi yang sama. Selain itu, masalah lain yang seringkali dihadapi adalah sulitnya mencegah kontaminasi sel, seperti perisit, sel otot polos, astrosit, dan sel fibroblas. ${ }^{5}$ Sel-sel yang menjadi kontaminan tersebut memiliki kecepatan tumbuh yang melebihi sel EPDO, sehingga keberadaannya mengganggu upaya ekspansi sel EPDO dalam cawan kultur. Setelah enam hari dikultur, hanya didapatkan $68,6 \%$ sel yang terbukti merupakan sel EPDO. $P$ - $g p$ merupakan gen multidrug resistance yang mengaktifkan efflux dari berbagai macam obat yang bersifat lipophilic. P-gp diekspresikan terutama dalam membran lumen sel EPDO. ${ }^{14,15}$ Pada percobaan ini kami memaparkan substrat $P_{-}$ gp (puromycin) pada kultur primer sel EPDO. Alasan ilmiah yang mendasari penggunaan puromycin, adalah sifat sel EPDO yang memiliki ekspresi $P$ - $g p$ yang tinggi sehingga memompa keluar puromycin, sedangkan sel kontaminan yang tidak memiliki $P$ - $g p$ akan mati.

Sistem transportasi obat melalui BBB banyak dipelajari menggunakan kultur sel EPDO dari bovine ataupun babi. ${ }^{16-18}$ Meskipun lebih mudah dilakukan, studi mengenai transpor obat melalui BBB akan lebih efektif apabila menggunakan binatang yang lebih kecil, terutama tikus. Korelasi antara hasil percobaan in vitro dan in vivo, dapat diperoleh dengan membuat sistem kulturisasi sel yang mudah dan dapat dipercaya. Pada penelitian ini, kami membuktikan bahwa isolasi sel EPDO dengan teknik pemurnian yang menggunakan puromycin, merupakan teknik kulturisasi sel secara primer yang dapat direpetisi dengan mudah dan memiliki konsistensi hasil yang sangat baik, terutama berdasarkan nilai kemurnian sel EPDO yang didapatkan. Sel EPDO juga diketahui dapat menstimulasi self-renewal pada adult neural stem cells dan menjadikannya sel neuron. ${ }^{19}$ Sel EPDO dapat dibiakkan bersama (co-culture) dengan neural stem cells (NSCs) untuk membuat kondisi menyerupai keadaan sebenarnya di dalam otak. Sistem yang dinamakan transwell co-culture ini, terdiri dari upper insert dan lower culture base. Pembatas bagian atas dan chamber merupakan membran microporous. Dengan sistem ini, interaksi langsung antara kedua tipe sel yang berbeda dapat dicegah, namun sinyal molekuler yang terjadi antara keduanya akan tetap dapat dihantarkan melalui microporous. Secara normal, NSCs diproduksi di daerah subventrikular dan hipokampus di dalam otak. NSCs tidak berinteraksi langsung dengan sel EPDO, karena terpisah membran basal. Sistem transwell coculture digunakan untuk mempelajari hubungan antar dua tipe sel yang saling berinteraksi satu dengan yang lainnya dalam suatu area yang sama, tanpa adanya interaksi langsung. Model ini menyerupai kondisi sebenarnya di otak. Selain itu, model ini juga digunakan untuk mempelajari microenvironment, niche, dan interaksi sinyal molekuler yang terdapat di dalamnya. Kegunaan lain sistem transwell co-culture, adalah untuk mempelajari morfologi, immunostaining, dan karakteristik molekuler sel yang hendak dipelajari. Sistem ini juga merupakan metode yang mudah diterapkan dalam melakukan pengamatan terhadap komunikasi antara dua tipe sel yang berbeda untuk mempelajari interaksi antar sel.

Teknik modifikasi metode isolasi sel EPDO dapat dipakai untuk melakukan isolasi dan 
mempelajari biologi sel pembuluh darah dari berbagai model hewan percobaan transgenik. Metode isolasi sel EPDO yang mudah, dapat direpetisi dan menghasilkan sel endotel yang murni tanpa kontaminasi sel-sel lain merupakan suatu kebutuhan. Unit Penelitian Kesehatan, Fakultas Kedokteran Universitas Padjadjaran, sejak tahun 1997 telah berhasil mengembangkan beberapa jenis kultur sel primer di laboratorium kultur sel dan jaringan, seperti sel fibrolas dari preputium maupun chick embryo, sel endotel porcine aorta, otot jantung dari mouse embryo, dan sel tiroid dari jaringan tumor tiroid. ${ }^{20}$ Protokol isolasi primer sel EPDO ini menambah daftar metode dan teknologi kultur sel primer yang dapat dikembangkan dan dipakai dalam penelitian program pascasarjana ataupun penelitian lainnya yang berkaitan dengan sistem pembuluh darah otak.

Disimpulkan bahwa metode modifikasi ini dapat digunakan untuk melakukan isolasi primer sel EPDO in vitro dengan mudah dan lebih aplikatif, karena menyerupai kondisi sebenarnya pada penelitian in vivo. Modifikasi protokol isolasi dan kulturisasi ini dapat membantu peneliti untuk mempelajari berbagai aspek biologi molekuler pembuluh darah otak, sehingga meningkatkan pemahaman peneliti dan klinisi mengenai proses fisiologis dan patofisiologis yang terjadi di dalam otak.

\section{Ucapan Terima Kasih}

Penulis mengucapkan terima kasih kepada Grup Peneliti Sel Punca, Unit Penelitian Kesehatan, Fakultas Kedokteran Universitas PadjadjaranRumah Sakit Dr. Hasan Sadikin dan Universitas Gunma, Jepang. Penelitian ini didanai oleh Fakultas Kedokteran Universitas Padjadjaran, Bandung untukAhmad Faried.

\section{Tinjauan Pustaka}

1. Cines DB, Pollak ES, Buck CA, Loscalzo J, Zimmerman GA, McEver RP, dkk. Endothelial cells in physiology and in the pathophysiology of vascular disorders. Blood. 1998;91:3527-61.

2. Sato Y. Current understanding of the biology of vascular endothelium. Cell Struct Funct. 2001;26:9-10.

3. Siakotos AN. The isolation of endothelial cells from normal human and bovine brain. Methods Enzymol. 1974;32:717-22.
4. Gerhart DZ, Broderius MA, Drewes LR. Cultured human and canine endothelial cells from brain microvessels. Brain Res Bull. 1988;21:785-93.

5. Greenwood J. Characterization of a rat retinal endothelial cell culture and the expression of Pglycoprotein in brain and retinal endothelium in vitro. J Neuroimmunol. 1992;39:123-32.

6. Deli MA, Abraham CS, Niwa M, Falus A. N,Ndiethyl-2-[4-(phenylmethyl) phenoxy] ethanamine increases the permeability of primary mouse cerebral endothelial cell monolayers. Inflamm Res. 2003;52:S39-40.

7. Bowman PD, Ennis SR, Rarey KE, Betz AL, Goldstein GW. Brain microvessel endothelial cells in tissue culture: a model for study of blood-brain barrier permeability. Ann Neurol. 1983;14:396402.

8. Yoshimoto S, Ishizaki Y, Kurihara H, Sasaki T, Yoshizumi M, Yanagisawa M, dkk. Cerebral microvessel endothelium is producing endothelin. Brain Res. 1990;508:283-5.

9. Perrière N, Demeuse $P$, Garcia E, Regina A, Debray M, Andreux JP, dkk. Puromycin-based purification of rat brain capillary endothelial cell cultures: effect on the expression of blood-brain barrier-specific properties. J Neurochem. 2005; 93:279-89.

10. Voyta JC, Via DP, Butterfield CE, Zetter BR. Identification and isolation of endothelial cells based on their increased uptake of acetylated-low density lipoprotein. J Cell Biol. 1984;99:2034-40.

11. Jaffe EA. Endothelial cells and the biology of factor VIII. N Engl J Med. 1977;269:377-83.

12. Omidi Y, Campbell L, Barar J, Connell D, Akhtar S, Gumbleton M. Evaluation of the immortalised mouse brain capillary endothelial cell Line, b.End3, as an in vitro blood-brain barrier model for drug uptake and transport studies. Brain Res. 2003;990:95-112.

13. Roux FS, Mokni R, Hughes CC, Clouet PM, Lefauconnier JM, Bourre JM. Lipid synthesis by rat brain microvessel endothelial cells in tissue culture. J Neuropathol Ex Neurol. 1989;48:43747.

14. Jetté L, Têtu B, Béliveau R. High levels of Pglycoprotein detected in isolated brain capillaries. Biochim Biophys Acta. 1993;1150:147-54.

15. Demeule M, Labelle M, Regina A, Berthelet F, Be'liveau R. Isolation of endothelial cells from brain, lung, and kidney: expression of the multidrug resistance P-glycoprotein isoforms. Biochem Biophys Res Commun. 2001;281:827-34.

16. Franke H, Galla HJ, Beuckmann CT. An improved low permeability in vitro-model of the blood-brain barrier: transport studies on retinoids, sucrose, haloperidol, caffeine and mannitol. Brain Res. 1999;818:65-71. 
17. Gaillard PJ, van der Sandt ICJ, Voorwinden LH, Vu D, Nielsen JL, de Boer AG, dkk. Astrocytes increase the functional expression of $\mathrm{P}$ glycoprotein in an in vitro model of the bloodbrain barrier. Pharm Res. 2000;17:1198-205.

18. Deli MA, Abraham CS, Kataoka Y, Niwa M. Permeability studies on in vitro blood-brain barrier models: physiology, pathology, and pharmacology. Cell Mol Neurobiol. 2005;25:59127.

19. Shen Q, Goderie SK, Jin L, Karanth N, Sun Y, Abramova N, dkk. Endothelial cells stimulate self-renewal and expand neurogenesis of neural stem cells. Science. 2004;304:1338-40.

20. Achmad TH. A decade of cell and tissue culture: the technology development and its implementation. MKB. 2008;40:93-7. 